since the remaining calves and the sire had been slaughtered before our examination began.

Of the 8 calves examined four showed $\mathbf{I} / 29$ translocation in the heterozygous state, one animal showed this translocation in the homozygous state and the remaining three calves were free of this aberration. None of the dams showed translocation. It is of interest to note that some quantitative cytogenetic data (counts of cells with breaks or gaps) obtained for the calves corresponded to those obtained for their dams.

The cytogenetic finding's are interpreted as indicating random association of two inherited ealth disorders.

\title{
R-Banding studies in Bos taurus and Ovis aries
}

\section{KOULISCHER and J. DIVOY}

\author{
29 bis, Allée des Templiers, \\ 6270 Loverval (Belgique)
}

The chromosomes of Bos taurus and Ovis aries have been studied using the R-banding technique (DUTRILLAUX and LEJEUNE, I97I). The banding pattern obtained allows an accurate identification of chromosome pairs, including those of Ovis aries involved in the centromeric fusion.

But the most striking observation concerns the centromeres. All centromeres appear darkly stained, just as if $\mathrm{C}$ - banding had been used. As a control, human chromosomes were stained in identical conditions, in the same containers than the Bovoidea chromosomes: the usual R-banding pattern of Man was observed. This shows first that the centromeric staining of Bos taurus and Ovis aries is not an artefact, second that very likely it is not constitutive heterochomatin that has been detected.

Should $R$ and $C$-banding be linked with the nature of the chromosomal DNA (eu - or heterochromatin, repetitive short or long DNA sequences, etc.), the present observation is suggestive of the presence of more than one kind of DNA at the centromeric region of the Bovoidea.

\section{Fertility of sires born as dizygotic twins and sex ratio in their progeny groups}

\section{GUSTAVSSON}

\author{
Department of Animal Genetics, Nutrition and Hygiene, \\ Royal Veterinary College, $H V C, S-750$ o7 Uppsala 7, Sweden
}

Often reduced fertility and deviating sex ratios in progeny groups have been reported for bulls born as dizygotic twins. Fxperience from the last 20 years' of A.I. work within the Swedish Red and White cattle breed is reported. A total of 33 bulls born as dizygotic twins and divided into three groups according to sampling method, were investigated with respect to semen quality and quantity, conception rate at first service, non-return (NR) rates of 28 and 56 days, and sex ratio of progeny groups. The information available neither point to deviating semen characteristics and reduced fertility of the bulls nor to deviating sex ratios of the progeny groups. Therefore the diagnosis " born as a twin " has hitherto been omitted from consideration in breeding work of cattle in Sweden.

\section{Disparition des cellules germinales et déroulement anormal de la méiose chez les fotus de veau freemartins}

\author{
J. PRÉPIN, B. VIGIER et A. JOST \\ Physiologie Comparée, 9, quai St-Bernard, 75 Paris-5e, France
}

L'effet freemartin se manifeste au niveau des glandes génitales vers $49-52$ j par un arrêt de leur croissance et par un ralentissement très marqué de l'augmentation du nombre des cellules germinales par rapport aux témoins. Le nombre des cellules germinales décroît à partir de 7o $\mathrm{j}$ et devient très faible à I $50 \mathrm{j}$. 
Le déficit en cellules germinales est loin de suffire à expliquer, à lui seul, 1'arrêt de croissance des gonades. Le déficit en tissu somatique est plus important. La différence de volume entre les gonades des freemartins et des foetus témoins est due pour 95 p. cent à une déficience en tissu somatique chez les foetus de 49 à $59 \mathrm{j}$ et pour 70 p. cent environ chez les fotus de 60 à I ro j. Cependant, chez les freemartins de 49 à $59 \mathrm{j}$, le nombre des cellules germinales par unité de volume gonadique est identique à celui des témoins. Il y a donc proportionnalité entre la réduction du nombre des cellules germinales et la réduction du volume de tissu somatique; ceci ne s'observe plus après $59 \mathrm{j}$.

La méiose apparaît chez tous les freemartins de plus de $77 j$, mais à chaque stade, elle ne concerne qu'un petit nombre des cellules germinales présentes. De plus, elle ne semble pas évoluer au delà du stade pachytène. Après le stade où sont apparues les premières figures de méiose, le nombre des cellules germinales contenues dans les gonades diminue beaucoup, il en subsiste encore quelques-unes après i $50 \mathrm{j}$, mais aucune n'est en méiose.

\title{
Cytogenetic and Reproductive studies of Bulls Born Co-Twin to Freemartins
}

\author{
H. O. DUNN, C. E. HALL and K. MCENTEE
}

N.Y.S. College of Veterinary Medicine, Cornell University, Ithaca N. Y. 14850, U.S.A.

Thirteen A.I. Center bulls, born twin to freemartins, were karyotyped. Records of reproductive performance were available on $\mathrm{I} 3$ and necropsy specimens on 8 . Fifty or more metaphases from cultured lymphocytes were scored to establish the XX/XY ratios. The percentage of XX cells, which ranged from $6 \mathrm{p}$. cent to $93 \mathrm{p}$. cent, were used to identify the bulls.

Five bulls ( $13 \mathrm{XX}, 36 \mathrm{XX}, 43 \mathrm{XX}, 60 \mathrm{XX}$, and $7 \mathrm{xXX}$ ) either failed to produce semen or the semen produced was below standards for sperm motility, concentration and morphology, and as young bulls they were culled. The highest percentage of abnormal sperm were observed in I 5 successive, unsatisfactory ejaculates of $60 \mathrm{XX}$.

The remaining eight bulls were used for artificial breeding. Four $6 \mathrm{XX}, 30 \mathrm{XX}, 63 \mathrm{XX}$, $84 \mathrm{XX})$ are now in-waiting for A.I. proofs. With the exception of $63 \mathrm{XX}$, which produced a high percentage of sperm with acrosomal defects, their sperm production and fertility as young bulls were satisfactory. Thirty-three p. cent of the frozen semen of the young bull $29 \mathrm{XX}$ was discarded, but freezability of his sperm appeared satisfactory as a 6-year-old when he was culled for A.I. production. Fertility of $33 \mathrm{XX}$ was below breed average. Two Holsteins, $85 \mathrm{XX}$ and $93 \mathrm{XX}$, were used as A.I. proven sires. Their sperm production as young bulls was below the average of their randomly chosen stablemates. There was a highly significant decline $(P<0.01)$ in $85 X X$ 's sperm production as a 6-year-old, and he was culled as an 8-year-old despite his good fertility record. Fertility of $93 \mathrm{XX}$ was slightly below breed average but semen samples were satisfactory until severe spondylosis at age ro complicated his semen collection.

The sex ratios of offspring of $29 \mathrm{XX}, 33 \mathrm{XX}$ and $85 \mathrm{XX}$ were obtained. A skewed male: female sex ratio of 29:7 $\mathrm{r}$ in offspring of $33 \mathrm{XX}$ was significant $(P<0.05)$. There was no evidence of germ cell chimerism based on blood typing of three offspring of $33 \mathrm{XX}$ and 23 offspring of $85 \mathrm{XX}$.

Necropsy specimens from ${ }_{13} \mathrm{XX}, 29 \mathrm{XX}, 36 \mathrm{XX}, 43 \mathrm{XX}, 60 \mathrm{XX}, 7 \mathrm{IXX}, 85 \mathrm{XX}$ and $93 \mathrm{XX}$ revealed various levels of testicular degeneration.

These results indicate that $\mathrm{XX} / \mathrm{XY}$ chimeric bulls are high risk sires for breeding purposes, probably as a result of hormonal deficiencies or invasion of the gonac ds with XX primordial germ cells.

\section{Le chimérisme $\mathrm{XX} / \mathrm{XY}$ ne joue pas de rôle dans la phase initiale du freemartinisme chez les bovins}

\author{
B. VIGIER, J. PREPIN, A. LOCATELLI, F. Du MESNIL du BUISSON et A. JOST \\ Physiologie Comparée, 9, quai St-Bernard, 75 Paris-5 ${ }^{\mathrm{e}}$, France
}

Le développement des anomalies sexuelles chez les foetus freemartins passe par deux phases successives distinctes: - entre 50 et $70 \mathrm{j}$, une phase initiale exclusivement d'inhibition (arrêt du développement de la gonade et régression des canaux de Müller comme chez les mâles) - après 